Louisiana State University

LSU Digital Commons

Faculty Publications

School of Animal Sciences

$11-1-2006$

\title{
Estradiol interactions with dopamine antagonists in mares: Prolactin secretion and reproductive traits
}

\author{
K. K. Kelley \\ LSU Agricultural Center \\ D. L. Thompson \\ LSU Agricultural Center \\ W. A. Storer \\ LSU Agricultural Center \\ P. B. Mitcham \\ LSU Agricultural Center \\ R. M. Gilley \\ BioRelease Technologies
}

See next page for additional authors

Follow this and additional works at: https://digitalcommons.Isu.edu/animalsciences_pubs

\section{Recommended Citation}

Kelley, K., Thompson, D., Storer, W., Mitcham, P., Gilley, R., \& Burns, P. (2006). Estradiol interactions with dopamine antagonists in mares: Prolactin secretion and reproductive traits. Journal of Equine Veterinary Science, 26 (11), 517-528. https://doi.org/10.1016/j.jevs.2006.09.008

This Article is brought to you for free and open access by the School of Animal Sciences at LSU Digital Commons. It has been accepted for inclusion in Faculty Publications by an authorized administrator of LSU Digital Commons.

For more information, please contact ir@lsu.edu. 


\section{Authors}

K. K. Kelley, D. L. Thompson, W. A. Storer, P. B. Mitcham, R. M. Gilley, and P. J. Burns 
Louisiana State University

LSU Digital Commons

LSU Master's Theses

Graduate School

2006

\section{Estradiol interactions with dopamine antagonists in mares: prolactin secretion and reproductive traits}

Kristian Kandis Kelley

Louisiana State University and Agricultural and Mechanical College

Follow this and additional works at: https://digitalcommons.lsu.edu/gradschool theses

Part of the Animal Sciences Commons

\section{Recommended Citation}

Kelley, Kristian Kandis, "Estradiol interactions with dopamine antagonists in mares: prolactin secretion and reproductive traits" (2006). LSU Master's Theses. 3082.

https://digitalcommons.lsu.edu/gradschool_theses/3082

This Thesis is brought to you for free and open access by the Graduate School at LSU Digital Commons. It has been accepted for inclusion in LSU

Master's Theses by an authorized graduate school editor of LSU Digital Commons. For more information, please contact gradetd@lsu.edu. 


\title{
ESTRADIOL INTERACTIONS WITH DOPAMINE ANTAGONISTS IN MARES:
} PROLACTIN SECRETION AND REPRODUCTIVE TRAITS

\author{
A Thesis \\ Submitted to the Graduate Faculty of the \\ Louisiana State University and \\ Agricultural and Mechanical College \\ in partial fulfillment of the \\ requirements for the degree of \\ Master of Science \\ in
}

The Interdepartmental Program in Animal, Dairy, and Poultry Sciences

By

Kristian Kandis Kelley

B.S., Southern Arkansas University, 2004

May 2006 


\section{ACKNOWLEDGMENTS}

I wish to express my greatest appreciation to my graduate advisor, Dr. Donald L. Thompson, Jr., for his patience, guidance, and support throughout my graduate career at LSU. Gratitude is also extended to the members of my graduate committee, Dr. Dale L. Paccamonti and Dr. Robert A. Godke, for their help and support with my thesis research. I am extremely indebted to Mr. Franklin "Randy" Wright for his management of the horses during these experiments.

A sincere thanks goes to my colleagues who have greatly helped me throughout my graduate career with great support and understanding. First, thank you William A. Storer for your many hours worked at the farm and much needed, directional advice with these intensive projects. A huge thanks goes to Pamela B. Mitcham for her many hard hours and helpful advice. A very special thanks goes to to John Vidrine for all his help and dedication. Jodi Crowley and Maxon McKean, thank you for your support, and Laura R. Gentry, thank you for the much appreciated help with data analysis and radioimmunoassay techniques. Also, gratitude is extended to all the student workers whose hard work, both in the lab and at the farm, was invaluable.

My most sincere appreciation is extended to my grandmother, Louise Wyrick, for her

support, love, and encouragement throughout my academic career. I also thank my family and friends for their advice, support, and love. 


\section{TABLE OF CONTENTS}

ACKNOWLEDGMENTS $\ldots \ldots \ldots \ldots \ldots \ldots \ldots \ldots \ldots \ldots$ ii

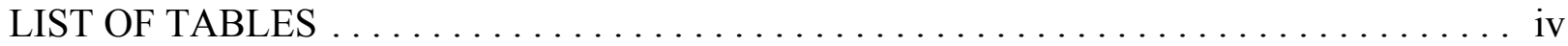

LIST OF FIGURES $\ldots \ldots \ldots \ldots \ldots \ldots \ldots \ldots \ldots \ldots \ldots \ldots \ldots \ldots \ldots \ldots$

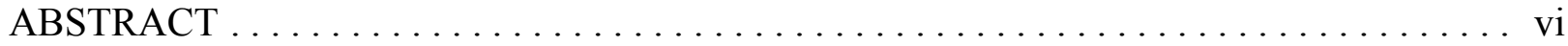

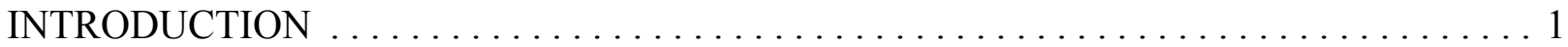

CHAPTER I. REVIEW OF LITERATURE $\ldots \ldots \ldots \ldots \ldots \ldots \ldots \ldots \ldots \ldots \ldots \ldots \ldots$

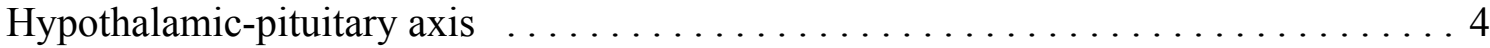

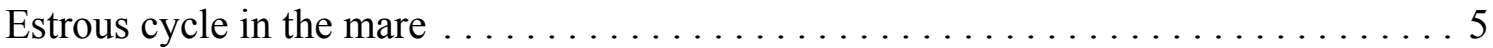

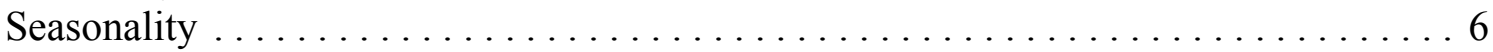

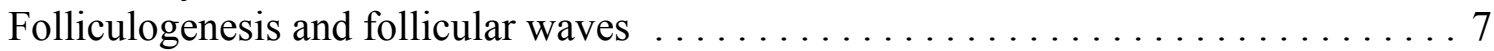

Ovulation and the luteal phase $\ldots \ldots \ldots \ldots \ldots \ldots \ldots \ldots \ldots \ldots \ldots \ldots \ldots \ldots$

Prolactin ......................................... 9

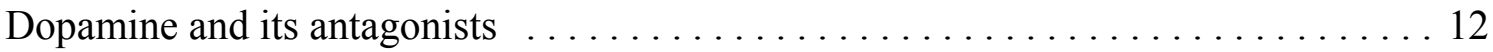

Rationale for present experiments ........................... 14

CHAPTER II. ESTRADIOL INTERACTION WITH SULPIRIDE IN SEASONALLY ANOVULATORY MARES: EFFECTS ON PLASMA PROLACTIN CONCENTRATIONS

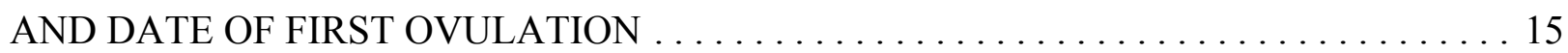

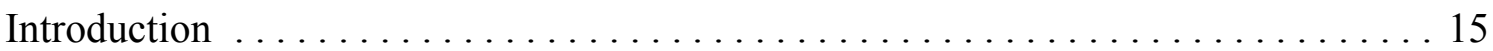

Materials and methods ................................... 16

Results .......................................... 18

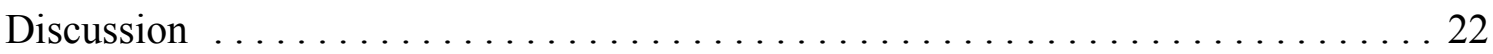

CHAPTER III. ESTRADIOL INTERACTION WITH A SINGLE INJECTION OF

DOMPERIDONE DURING THE BREEDING SEASON IN MARES: PROLACTIN

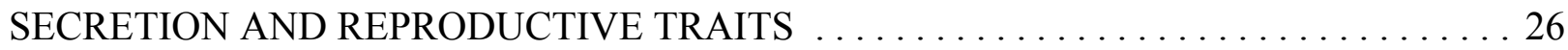

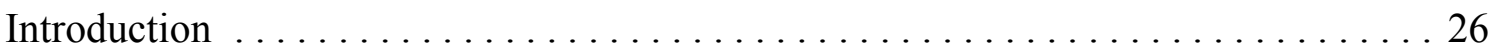

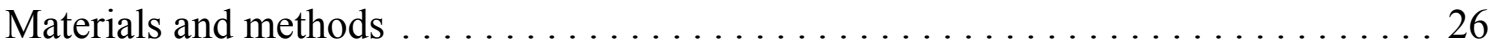

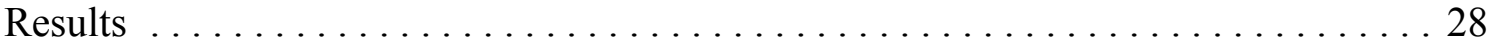

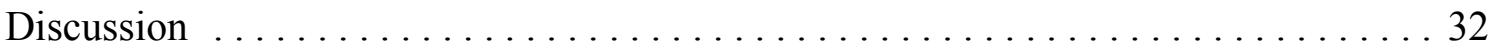

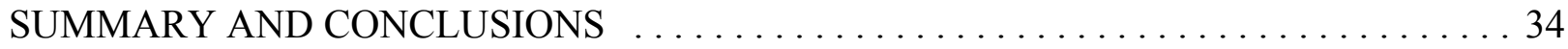

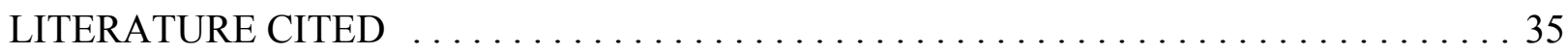

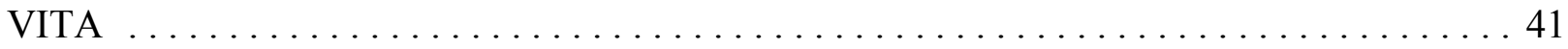




\section{LIST OF TABLES}

2.1 Mean age, body condition score (BCS), and day of first ovulation (based on ultrasound exam and progesterone concentration) of mares pretreated with estradiol benzoate or vehicle (control) before daily administration of sulpiride (d 11 to 45$) \ldots \ldots \ldots 22$

3.1 Mean time to first ovulation, time until CL regression (as determined by a drop in progesterone concentrations), time to next CL formation (high progesterone), and time of second CL regression (drop in progesterone) of mares pretreated with estradiol benzoate or vehicle (control) before a single injection of

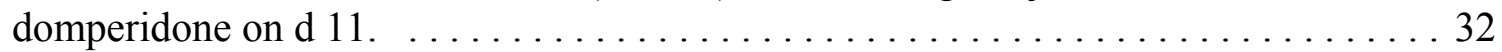




\section{LIST OF FIGURES}

2.1 Mean plasma concentrations of prolactin over time for mares pretreated with estradiol benzoate (Estradiol) or vehicle (Control) before onset of daily sulpiride

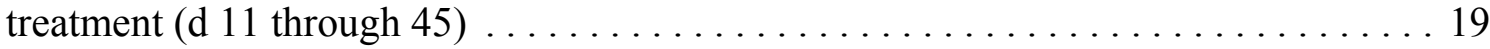

2.2 Mean plasma prolactin concentrations around the time of sulpiride injections on $\mathrm{d} 11$ (first injection), 13, 17, and 25 in mares pretreated with estradiol benzoate

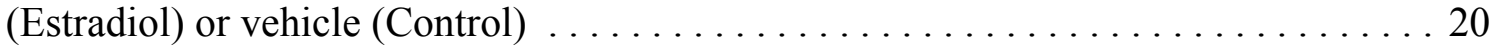

2.3 Mean plasma prolactin concentrations around the time of TRH administration on d 24 in mares pretreated with estradiol benzoate (Estradiol) or vehicle (Control) . . . 21

3.1 Mean plasma concentrations of prolactin over time for mares pretreated starting on $\mathrm{d} 0$ with estradiol benzoate (Estradiol) or vehicle (Control) before a single

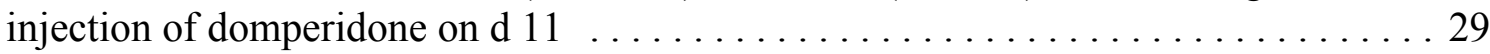

3.2 Mean plasma prolactin concentrations around the time of domperidone injection on $\mathrm{d} 11$ in mares pretreated with estradiol benzoate (Estradiol) or vehicle (Control) . . 30

3.3 Mean plasma prolactin concentrations around the time of TRH administration on d 21 in mares pretreated with estradiol benzoate (Estradiol) or vehicle (Control) . . 31 


\begin{abstract}
Two experiments studied the effects of pretreatment with estradiol benzoate before treatment with a dopamine antagonist on prolactin secretion and reproductive traits in mares during 1) the seasonal anovulatory period and 2) the normal breeding season. Experiment 1 was performed in winter with 17 mares selected for low follicular activity. Nine mares received estradiol benzoate injections every other day for a total of 10 injections; 8 mares received similar injections of vehicle. Ten days after onset of injections, all mares were placed on a daily injections of sulpiride $(250 \mathrm{mg})$ for $45 \mathrm{~d}$ or until ovulation. Plasma prolactin concentrations were higher $(\mathrm{P}<0.001)$ in mares receiving estradiol than in control mares for all assessments from d 12 through 36. Mean day of ovulation was $73.6 \mathrm{~d}$ for control mares and 29.0 for estradiol-treated mares $(\mathrm{P}=0.016)$. It was concluded that estradiol treatment greatly enhanced prolactin secretion in response to sulpiride in seasonally anovulatory mares and hastened the date of first ovulation by an average of $45 \mathrm{~d}$. Experiment 2 was designed to assess the efficacy of a single injection preparation of another dopamine antagonist, domperidone, for increasing prolactin secretion in cyclic mares in the summer. The experimental design and procedures used in Experiment 1 were repeated, except that a single shot of $3 \mathrm{~g}$ of domperidone was administered on $\mathrm{d} 11$ rather than $45 \mathrm{~d}$ of sulpiride injections. Day 0 was the first day of estrus for each mare. Prolactin concentrations were higher $(\mathrm{P}<0.05)$ in mares receiving estradiol than in control mares from d 12 through 25 and after a thyrotropin releasing hormone injection on $\mathrm{d}$ 21. It was concluded that estradiol enhanced the prolactin response to a single injection of $3 \mathrm{~g}$ of domperidone in cyclic mares in the summer in a manner similar to the estradiol enhancement of prolactin secretion in response to daily sulpiride injections in anovulatory mares in winter. Thus, the single injection of domperidone could possibly replace the daily sulpiride injections
\end{abstract}


used in Experiment 1 to induce ovulation in seasonally anovulatory mares; this needs to be tested in future experiments. 


\section{INTRODUCTION}

Prolactin is a pituitary hormone primarily thought to regulate lactation; however, previous research has indicated that it is also actively involved in reproduction in mares. Horses are seasonally reproductive animals, experiencing estrous cycles during the spring and summer months and a period of ovarian inactivity during the winter (Ginther, 1992; Daels and Hughes, 1993). Thompson et al. (1986) reported that horses have higher prolactin levels during the breeding season, with mares having the highest levels. Mares undergoing transition from the anovulatory season in winter to the breeding season experience increases in several hormones, including prolactin. This "transition" period may also involve the development and growth of large follicles for a long period of time without ovulation (Sharp and Davis, 1993). Concentrations of luteinizing hormone (LH) remain low until the first pre-ovulatory surge (Hines et al., 1991). Hines et al. (1991) also showed that the mare will often have long erratic displays of estrus towards the stallion during this time.

Because most breed associations use the single-date, January 1 birth date for all foals born in a calender year, many horse breeders invest considerable time and effort into getting broodmares pregnant around February $15^{\text {th }}$, so that the resulting foals will be born around, but not before, January $1^{\text {st }}$ of the following year. It is thought by many that these "early-born" foals will have a physical advantage over foals born later in the spring. That is, a foal born January $1^{\text {st }}$ would have a 5-mo size advantage over a foal born June $1^{\text {st }}$ at a yearling sale the following year. Thus, a simple and economical method of inducing ovarian activity and ovulation in February is desirable. Moreover, avoiding the erratic estrous cycles typical of the transition period is also a common goal of breeders in February. 
Several research groups have shown that increasing prolactin in mares in winter aids in the development of follicles and, in some cases, ovulation. Besognet et al. (1997) and Redmond et al. (1997) reported an increase in prolactin concentrations after administration of either of two dopamine antagonists, sulpiride or domperidone. Donadeu and Thompson (2002) reported that treatment of anovulatory mares with sulpiride increased prolactin levels but did not adequately stimulate follicular development in the winter. Nequin et al. (1993) reported that increases in prolactin levels during the winter, either by a dopamine antagonist administration or by injection of bovine prolactin, stimulated follicular growth positively and rapidly. In addition, Thompson et al. (1991) reported that administration of recombinant porcine prolactin daily to seasonally anovulatory pony mares resulted in ovulation or corpus luteum (CL) formation within $21 \mathrm{~d}$.

One explanation for mediocre or poor stimulation of follicular activity in mares in winter treated with sulpiride (Besognet et al., 1997; Donadeu and Thompson, 2002) has been inadequate prolactin secretion in response to the sulpiride injections. Thompson and Depew (1997) showed that prolactin responses to daily sulpiride injections in geldings in winter dropped quickly after the first injection, indicating that prolactin production by the pituitary was likely not stimulated. One missing factor in seasonally anovulatory mares (and geldings) that may account for the poor prolactin response to sulpiride is estrogen, which has been reported to increase prolactin production and secretion in ovariectomized mares in summer (Thompson et al., 1991). Thus, the objective of the first experiment presented herein was to test whether pretreatment with estradiol benzoate before treatment with daily sulpiride injections would enhance the prolactin response, and hence the ovarian response, of seasonally anovulatory mares. Given the positive response to estradiol observed in the first experiment, the second 
experiment was designed to test whether estradiol pretreatment would enhance the prolactin response to a single, 3 -g injection of domperidone, which could potentially be used in lieu of daily sulpiride injections in the winter stimulatory regimen. Experiment 2 was performed in summer with normally cyclic mares. 


\section{CHAPTER I}

\section{REVIEW OF LITERATURE}

\section{Hypothalamic-pituitary axis}

Extensive research has been conducted on the hypothalamic-pituitary gonadal axis that strongly reinforces the idea that it is a prominent key in reproduction. The hypothalamus accumulates information from outside stimuli and converts those neural signals into hormonal signals (Guyton and Hall, 1996). The hypothalamus produces the essential regulatory hormone of reproduction: gonadotropin releasing hormone $(\mathrm{GnRH})$, which is localized evenly in all areas of the hypothalamus in mares (Irvine and Alexander, 1993). Secretory granules release GnRH into capillaries of the primary plexus; this released GnRH travels to receptors on gonadotropes in the pars distalis in the adenohypophysis of the pituitary via the hypophysial portal veins (Alexander and Irvine, 1993; Kainer, 1993).

Gonadotropin releasing hormone stimulates production of its own receptors on gonadotropes (Clayton, 1989; Alexander and Irvine, 1992). Gonadotropin releasing hormone also stimulates LH and follicle stimulating hormone (FSH) production and secretion in the adenohypophysis, which further affect reproduction in the horse. Free GnRH receptors limit the action of GnRH; estradiol can induce more receptors (Alexander and Irvine, 1993).

The hypothalamus secretes $\mathrm{GnRH}$ in pulses lasting 5 to 25 min occurring every 1 to $2 \mathrm{~h}$ (Guyton and Hall, 1996). This is suggested to control the differential release of the gonadotropins (Dyer, 1989; Ginther, 1992). Luteinizing hormone production and secretion correspond with rapid pulses (e.g., every $45 \mathrm{~min}$ ), while pulses every 6 h results in mainly FSH secretion (Alexander and Irvine, 1993). This relates to the fact that, during estrus, GnRH pulses are increased to $2 / \mathrm{h}$ and $\mathrm{LH}$ is high while $\mathrm{FSH}$ is low. In contrast, during diestrus, GnRH pulses 
occur an average of 2/d while FSH is increased and LH is decreased (Alexander and Irvine, 1993).

The two gonadotropins exert their effect through extracellular receptors on the ovaries. Receptors for FSH are found on granulosa cells and receptors for LH are found on thecal cells of pre-antral follicles (Alexander and Irvine, 1993).

\section{Estrous cycle in the mare}

In relation to breeding, the mare has two phases that make up the well-known estrous cycle: estrus and diestrus. The estrous cycle is from the start of one estrus to the start of the next (Daels and Hughes, 1993). The cycle is controlled by daylight and environmental effects (Ginther, 1992); the average estrous cycle is $21.7 \mathrm{~d}$, ranging from 19.1 to $23.7 \mathrm{~d}$. During the estrous cycle, the phase in which follicular growth is most prominent is estrus (Daels and Hughes, 1993). The period between ovulation and the onset of the next estrus is known as diestrus (Daels and Hughes, 1993). The average lengths for estrus and diestrus are 6.5 and 15.2 d, respectively. During estrus, FSH stimulates follicles; upon selection of a dominant follicle, estrogen is produced, causing expression of estrous behavior. Increased LH concentrations result in ovulation of the oocyte from the dominant follicle 24 to $48 \mathrm{~h}$ before the end of estrus. Development of a CL begins after ovulation.

The CL begins the diestrous phase by secreting increased amounts of progesterone (Daels and Hughes, 1993). During diestrus, the mare is unreceptive to the stallion. The increased levels of progesterone feed back negatively on the pituitary gland causing decreased LH secretion (Miller et al., 1980). Plasma concentrations of LH peak 1 d post-ovulation before decreasing. High levels of FSH occur in diestrus and are due to the lack of negative feedback by estradiol and inhibin (Freedman et al., 1979). Towards the completion of diestrus, the CL 
regresses due to lysis by prostaglandin $\mathrm{F}_{2 \alpha}\left(\mathrm{PGF}_{2 \alpha}\right)$, and the mare returns to estrus in 1 to $3 \mathrm{~d}$ (Daels and Hughes, 1993).

\section{Seasonality}

Mares are seasonally polyestrous, meaning they have multiple estrous cycles during summer months and become acyclic in the winter (Daels and Hughes, 1993). If a mare is not bred during the breeding season, she will display several repeated periods of estrus (Sharp and Davis, 1993).

The period from a mare's last ovulation of a particular breeding season until the first ovulation of the next is considered the anovulatory season (Ginther, 1992). The anovulatory season is characterized by three phases. The first, in which large follicles may form but fail to ovulate, is known as the receding phase (Ginther, 1992). The second, in which very few follicles grow beyond 10 to $20 \mathrm{~mm}$, is the inactive phase. Finally, the resurging phase is the beginning of recovery from the inactive phase. During the receding phase, follicles fail to ovulate due to insufficient LH secretion needed for ovulation (Snyder et al., 1979). This period can also be defined as sexual incompetence and indifference during winter months according to Sharp and Davis (1993). They also explain that this lack of reproductive activity is due to a decrease in GnRH secretion. Thompson et al. $(1986,1987)$ reported a distinct suppression of secretion of the gonadotropins in the winter months. Some mares may display weak signs of estrus during the inactive phase, even when follicular growth is absent (Ginther, 1992; Gentry et al., 2002).

When a mare begins to return to the ovulatory season and begin a period of long follicular growth before ovulation, she is said to be in the resurging phase, or vernal (spring) transition. Sharp and Davis (1993) reported the length of the time between the initial increase 
in FSH and first ovulation to be lengthy. Concentrations of FSH fluctuate, but LH remains low until right before the first ovulation (Hines et al., 1991). Freedman et al. (1979), Silvia et al. (1986), and Hines et al. (1991) all reported a decrease in the FSH pulse amplitude as the first ovulation approached, due to the increased production of inhibitory factors (estradiol and inhibin) from the large follicles (Miller et al., 1981). During vernal transition, LH release is stimulated by increasing GnRH concentrations, along with steroidogenically competent follicles, which result in a peripheral increase in estrogen concentrations (Sharp and Davis, 1993). The increasing estradiol levels positively feedback to stimulate more LH secretion. When sufficient LH has been secreted for a sufficient amount of time, ovulation occurs.

\section{Folliculogenesis and follicular waves}

A mare's ovary contains many follicles, which are the basic units of germ cell development. The ovary has both endocrine and exocrine functions (Pierson, 1993). Hormones are released into circulating blood that perfuses the follicles. The ovary is also controlled by local intercellular diffusion, called paracrine control, and release of substances that bind the cell's own receptors, otherwise known as autocrine control (Pierson, 1993).

The physical aspect of follicle formation and gradual development up to ovulation is referred to as folliculogenesis. The mare, like other mammalian females, is born with a fixed number of unreplenished follicles (Ginther, 1992). These follicles are simply an oocyte surrounded by a layer of cells. Follicular growth also includes oocyte growth, development of a zona pellucida, and then division of granulosa cells into epithelium (Pierson, 1993).

Development to this stage $(10 \mathrm{~mm}$ in diameter) is not controlled by gonadotropins (Pierson, 1993). Thereafter, without LH and FSH, follicles become atretic. 
Many follicles grow and regress without ever ovulating, making size an important factor. Ginther (1992) described three major sizes (diameters) of ovarian follicles: small (2 to $10 \mathrm{~mm}$ ), medium (11 to $24 \mathrm{~mm}$ ) and large $(\$ 25 \mathrm{~mm})$. The number of small follicles is little in the preovulatory stage when compared to the increased number during a postovulatory stage (Pierson, 1993). During the luteal phase, FSH increases the number of small follicles (Ginther and Bergfelt, 1993). Ginther et al. (2001) explained that after a follicle reaches $13 \mathrm{~mm}, \mathrm{FSH}$ decreases and estradiol, free IGF-1, activin-A, and inhibin-A begin to increase differentially. This allows for deviation of a dominant follicle with more responses to LH and FSH. This deviation begins after the two largest follicles reach an average 19.0 to $22.5 \mathrm{~mm}$. As the dominant follicle grows and produces more estradiol and inhibin, it causes atresia of the other medium and large follicles (Ginther, 1992; Pierson, 1993).

The emergence of small follicles and growth to medium follicles appears to occur in "waves" in mares, as has been reported for other species (Ginther, 1992; Pierson, 1993). Pierson (1993) attributes these waves to bimodal and unimodal surges in FSH concentrations during diestrus. Ginther and Bergfelt (1993) also state that follicular waves are due to FSH levels. Ginther (1992) defines these types of actions as several follicles initially growing in synchrony (same size and rate), but they eventually dissociate to allow a dominant follicle. All mares have at least 1 follicular wave, while some mares have 2 follicular waves, per estrous cycle. The secondary wave is the first wave to take place after ovulation, generally during early diestrus. The dominant follicle from this wave rarely ovulates, but usually regresses. The primary wave eventually produces a new dominate follicle that will ovulate independently from the first wave. This follicle is more responsive to steroid and gonadotropin stimulation due to increased receptors for FSH and LH on the granulosa and theca cells (Pierson, 1993). 


\section{Ovulation and the luteal phase}

Ovulation starts the luteal phase in the mare. During the start of this phase, the granulosa cells of the dominate follicle lutienize, and by d 3, a CL is formed (Niswender and Nett, 1993). The CL then produces progesterone throughout its life span. Progesterone increases receptors for LH so that LH can continually be utilized for support by the CL. By d 9, progesterone has reached a maximum, along with maximum growth of the CL. If the mare is not pregnant, the uterus will begin secreting $\mathrm{PGF}_{2 \alpha}$ around $\mathrm{d} 13$ or 14 , which will cause regression of the CL and a drop in progesterone secretion. This marks the end of the luteal phase and begins the next estrous cycle.

\section{Prolactin}

Prolactin is a single-chain protein made up of 199 amino acids (Nett, 1993). It is a hormone produced in the lactotropes of the adenohypophysis (Hadley, 2000). Prolactin is usually associated with pregnancy and lactation, and it has only recently been associated with reproductive functions in males and non-pregnant females of several species. Prolactin has a wide range of biological actions in various species. In 1928, Stricker and Grueter (cited by Hadley, 2000) observed a direct action of prolactin by using an extract of the anterior pituitary to stimulate milk secretion in rabbits. In 1933, Riddle, Bates, and Dykshorn (cited by Hadley, 2000) first observed that growth of crop sacs in pigeons was stimulated by bovine pituitary extracts, and they named the hormone prolactin. In many species, prolactin has effects on sebaceous glands, luteal tissue, and pelage, along with the prominent action in mammary glands (Hadley, 2000). Prolactin has often been referred to as the "maternity hormone" after its major role in pregnancy and lactation. Lactotropes make up $6.5 \%$ to $16.5 \%$ of the equine pituitary gland (Rahmanian et al., 1997). When prolactin was injected directly into ducts 
of the mammary gland, only alveoli around the site of injection produced milk, suggesting that prolactin needs actions from other hormones as well.

Prolactin increases at puberty, but only to a minor degree compared with LH and FSH. Also, the estrogen experienced at puberty is stimulatory to prolactin secretion. Prolactin has been shown to have profound effects on LH, and may influence it during puberty. Prolactin has been shown to increase LH receptors on Leydig cells in males (Purvis and Hassen, 1978; Bartke et al., 1980; Van Stralen and Zeilmaker, 1982) and on granulosa and luteal cells of females (Jones and Hsueh, 1981; Van Straalen and Zeil, 1982). In male rats, prolactin treatment prevents loss of LH receptors on Leydig cells. In stallions, prolactin may regulate seminal volume (Thomson et al., 1996). Prolactin is also responsible for hair shedding in horses (Thompson et al., 1997) and sheep (Lincoln and Tortonese, 1995).

In horses, Roser et al. (1987) showed that equine prolactin secretion is episodic in nature. Johnson (1986) reported an increase in prolactin concentration during the breeding season, and mares had an even greater increase in prolactin concentrations than stallions or geldings (Thompson et al., 1986). Prolactin concentrations in horses are directly correlated with photoperiod and temperature (Johnson, 1986; Thompson and Johnson, 1987). Increasing photoperiod during winter hastened the onset of increased prolactin concentrations (Johnson, 1987). Fitzgerald and McManus (2000) showed that increased melatonin during short photoperiod decreased prolactin concentration.

Prolactin is primarily regulated by dopamine secreted from the hypothalamus (Hadley, 2000). Dopamine is said to be the prolactin inhibiting factor (Neill et al., 1981; Ben Jonathan, 1985). Lactotropes removed from hypothalamic input secrete large amounts of prolactin (Hadley, 2000). This is because they spontaneously depolarize and secrete prolactin without 
the tonic inhibition from dopamine (Hadley, 2000). Thomson et al. (1996) reported the inhibitory effects on prolactin concentrations in stallions by the dopamine agonist, bromocriptine. In female rats, suppression of prolactin with bromocriptine retarded normal follicular development and delayed puberty (Advis et al., 1981). Opioid peptides may also play a physiological role in controlling the release of pituitary hormones (Hadley, 2000).

Endogenous opioid peptides inhibit dopaminergic pathways that control hormones from the hypothalamus, such as prolactin (Hadley, 2000).

In most mammalian species studied, prolactin is secreted in response to the hypothalamic thyroid regulating hormone, thyrotropin releasing hormone (TRH); this apparently is via specific receptors for TRH on lactotropes (Gerschengorn et al., 1979). Administration of TRH has been shown to increase plasma prolactin concentrations in horses as well (Johnson, 1986; Johnson and Becker, 1987; Colborn et al., 1991; Gentry et al., 2002b). Although it has consistent secretory effects on prolactin, TRH is not thought to be a normal physiologic regulator of prolactin secretion. As evidence of this in horses, Pruett et al. (2003) fed stallions 6-n-propyl-2-thiouracil to reduce thyroid hormone production (potentially increasing endogenous TRH secretion by the hypothalamus), and prolactin secretion was not altered.

Placing nonpregnant mares under artificial long photoperiods, simulating summer conditions, in winter is a commonly used method for inducing earlier ovarian activity and ovulation dates (Kooistra and Ginther, 1975; Sharp et al., 1975; Oxender et al., 1977). Artificial lighting also stimulates an increase in prolactin concentration. Johnson and Malinowski (1986) reported that just $2 \mathrm{~h}$ of artificial light during normal darkness of winter increased plasma prolactin concentration in mares. Although effective, artificial photoperiods 
usually require more input of labor and modified facilities than most producers wish to invest, thus alternative methods are constantly under investigation.

Pharmacologic methods of increasing prolactin secretion generally involve dopamine antagonists. Dopamine antagonists have been reported to increase prolactin concentration levels in the mare, especially during anestrus (Brendemuehl and Cross, 2000). Domperidone increased prolactin concentration more than sulpiride in a project by Redmond et al. (1994).

Steroids have also been reported to affect prolactin levels. Thompson et al. (1991) reported a 5-fold stimulation of prolactin storage in the pituitary by estradiol in ovariectomized mares, whereas the effect on plasma concentrations was much less. Aurich et al. (1995) reported an increase in prolactin concentration in overiectomized mares after administration of estrogen plus naloxan, an opiod antagonist.

\section{Dopamine and its antagonists}

Dopamine is a catecholamine derived from tyrosine that can act either as a neurohormone or a neurotransmitter (Hadley, 2000). As a neurohormone, dopamine is a chemical messenger released into the bloodstream by nerve cells (Hadley, 2000). After dopamine is released, it activates dopamine receptors, and the net effect is generally inhibitory on post-synaptic neurons. Kebabian and Calne (1979) reported that dopamine has two receptor subtypes: D-1 and D-2. The subtype involved with prolactin secretion from lactotropes is D-2 (Munemura et al., 1980; Creese et al., 1983). Western blot analysis and immunohistochemistry with ovarian tissue from mares revealed that D-2 receptors were highly concentrated in CL tissue and ovarian cortex, but were low in granulosa and theca cells; D-1 receptors were found only in CL tissue (King et al., 2005). The authors suggested that dopamine may act directly on the ovaries. 
Sulpiride is a widely used D-2 dopamine receptor antagonist that is cheap and readily available. Johnson and Becker (1987) first reported that sulpiride stimulated prolactin secretion in horses. Many studies have followed in mares (Nadal et al., 1997; Gentry et al., 2002a), stallions (Colborn et al., 1991; Thomson et al., 1996), and geldings (Thompson and Depew, 1997). Remond et al. (1994) used sulpiride to increase prolactin levels to treat fescue toxicosis in pregnant mares. In relation to non-treated mares, by $9 \mathrm{~d}$ after the start of treatment, the mares treated with sulpiride had increased prolactin concentrations (Redmond et al., 1994). In a study with seasonally anestrus mares treated with sulpiride daily, prolactin concentrations and ovulation dates were measured (Besognet et al., 1997). The study showed that mean ovulation date for sulpiride-treated mares was significantly earlier than for non-treated mares (Besognet et al., 1997). These ovulations occurred on $\mathrm{d} 127$ of the year, and mares continued to cycle (Besognet et al., 1997). This group showed an increase in prolactin concentrations at 2 and $9 \mathrm{~h}$ after sulpiride administration; prolactin returned to basal levels by $24 \mathrm{~h}$. In an earlier study by Besognet et al. (1997), 6 mares treated with sulpiride were bred during the first estrus along with 6 non-treated mares, and it was found that sulpiride did not affect fertility.

Domperidone is a D-2 dopamine receptor antagonist that is orally active. It has been used in human medicine to suppress nausea and vomiting (Dahlof and Hargreaves, 1998; Cinquetti et al., 2000). In the horse, domperidone has been used to treat fescue toxicosis because it increases prolactin concentrations. Given its positive effects on prolactin secretion, domperidone has also been studied for its reproductive applications. Domperidone is rapidly absorbed, but it does not cross the blood-brain barrier, and thus does not enter the central nervous system (Champion et al., 1986). Redmond et al. (1994) reported a greater stimulation of prolactin levels in mares treated with domperidone than in control mares and even sulpiride- 
treated mares. In a follow-up experiment, Brendemuehl and Cross (2000) treated anestrus mares with domperidone for $55 \mathrm{~d}$. By d 14 of treatment, mares receiving domperidone had larger follicles than non-treated mares, and overall, had ovulation dates that were earlier and prolactin levels that were higher.

\section{Rationale for present experiments}

Considerable interest exists in the breeding industry to induce early ovulation in order to obtain foals earlier in the year. Administration of domperidone has yielded increased prolactin levels and some success in inducing earlier ovulation dates in mares, however results with sulpiride have been less successful. Estradiol is known to increase secretion and pituitary storage of prolactin in ovariectomized mares, and may be the missing factor in sulpiride-treated, seasonally anovulatory mares. Thus, the objective of the first experiment presented herein was to test whether pretreatment with estradiol benzoate before treatment with daily sulpiride injections would enhance the prolactin response, and hence the ovarian response, of seasonally anovulatory mares. Given the positive response to estradiol observed in the first experiment, the second experiment was designed to test whether estradiol pretreatment would enhance the prolactin response to a single, 3 -g injection of domperidone, which could potentially be used in lieu of daily sulpiride injections in the winter stimulatory regimen. Experiment 2 was performed in summer with normally cyclic mares. 


\section{CHAPTER II}

\section{ESTRADIOL INTERACTION WITH SULPIRIDE IN SEASONALLY \\ ANOVULATORY MARES: EFFECTS ON PLASMA PROLACTIN CONCENTRATIONS AND DATE OF FIRST OVULATION}

\section{Introduction}

Prolactin seems to be an important factor in the timing of seasonal recrudescence of anovulatory mares back into the breeding season. Treatment of seasonally anovulatory mares with bovine prolactin (Nequin et al., 1993) or recombinant porcine prolactin (Thompson et al., 1997) induced ovarian activity and ovulation significantly earlier in the year than occurred in non-treated mares. Stimulation of endogenous prolactin secretion with dopamine antagonists has also been reported to hasten the onset of follicular activity and ovulation, but to varying degrees of success. Besognet et al. (1997) treated anovulatory mares with sulpiride beginning February 5 and hastened ovulation by 33 d. In contrast, Donadeu and Thompson (2002) treated mares with sulpiride from January 14 through February 14, and no mare ovulated within that period of time. Using oral domperidone rather than sulpiride injections, Brendemuehl and Cross (2000) treated mares beginning January 15 until ovulation and hastened mean date of ovulation by $78 \mathrm{~d}$.

Estradiol has been reported to increase prolactin secretion and pituitary prolactin content in ovariectomized pony mares in summer (Thompson et al., 1991), although the effect of estradiol on prolactin in the winter is unknown. It is possible that estrogen is the missing factor resulting in less than ideal ovarian responses to sulpiride in seasonally anovulatory mares. Thus, the present experiment was designed to test whether estradiol pretreatment of seasonally anovulatory mares would enhance the prolactin and ovarian responses to a daily regimen of sulpiride. 


\section{Materials and methods}

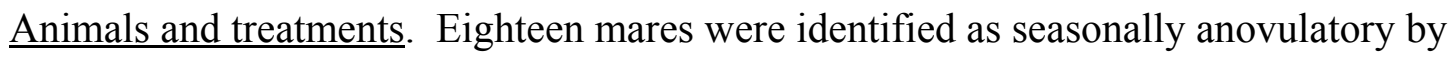
ultrasonographic examination of the ovaries in late December and early January; progesterone concentrations were used after-the-fact to confirm the lack of ovulation or luteal tissue. All mares were Quarter Horse or Thoroughbred type ranging in age from 7 to $17 \mathrm{yr}$ with body condition scores of 5.5 to 8 (Henneke et al., 1983). On January 11 (d 0), mares were randomly allotted to 2 groups: estradiol-treated $(n=9)$ and controls $(n=9)$. Beginning on d 0 , treated mares received i.m. injections of $11 \mathrm{mg}$ of estradiol benzoate (Sigma Chem. Co., St. Louis, MO) in vegetable oil ( $2 \mathrm{~mL})$ every other day for a total of 10 injections. Control mares received equivalent injections of the vehicle. Beginning on d 11 (halfway through the estradiol and vehicle treatments), all mares were started on a daily s.c. injection regimen of $250 \mathrm{mg}$ of sulpiride in $1 \mathrm{~mL}$ of vegetable shortening. Sulpiride injections were continued until a mare ovulated or through d 45, whichever occurred first.

Samples of blood were collected by jugular venipuncture from each mare on the mornings of $\mathrm{d}-1,0,1,2,5$, and 11 (before treatments) and then every $3 \mathrm{~d}$ thereafter. Once a mare displayed an ovarian follicle of at least $25 \mathrm{~mm}$, blood samples were collected daily until 5 d after ovulation.

In addition to the routine morning blood samples, frequent blood samples $(0,1,2,4,6$, 8 , and 12 h relative to injection of sulpiride or vehicle) were also collected on $\mathrm{d} 11,13,17$, and 25 for characterization of the prolactin response to injections. Beginning on $\mathrm{d} 20$, all mares had their ovaries scanned every $3 \mathrm{~d}$ to assess follicular sizes; once a mare displayed an ovarian follicle of at least $25 \mathrm{~mm}$, she was scanned daily until ovulation. 
On the morning of $\mathrm{d} 24$, all mares were catheterized in one jugular vein in preparation for frequent blood sampling. Approximately $1 \mathrm{~h}$ later, 2 samples of blood were drawn from the catheter $15 \mathrm{~min}$ apart (-15 and $0 \mathrm{~min}$ ), and then TRH (Sigma) was administered (5 $\mathrm{mg}$ in $2 \mathrm{~mL}$ saline). Blood samples were drawn at 15, 30, 45, 60, 90, 120, 150, 180, and 240 min relative to TRH administration. On that day, sulpiride and vehicle injections were delayed until all 240-min samples were collected.

Blood sample collection and analysis. Routine morning blood samples were collected into sodium heparin coated tubes (Vacutainer, Becton and Dickinson, Franklin Lakes, NJ). Frequent samples collected through catheters were placed in 12 x 75 glass tubes containing 20 IU sodium heparin (Sigma). All blood samples were routinely centrifuged within 30 min of collection; plasma was harvested and stored frozen.

Prolactin concentrations were estimated in plasma by radioimmunoassay previously validated for horse tissues (Colborn et al., 1991). Plasma concentrations of progesterone were measured with commercially available reagents (Diagnostic Systems Laboratories, Webster, TX). Intra- and interassay $\mathrm{CV}$ and assay sensitivities were 7\%, 12\%, and $0.2 \mathrm{ng} / \mathrm{mL}$ for prolactin and $5 \%, 8 \%$, and $0.1 \mathrm{ng} / \mathrm{mL}$ for progesterone.

Statistical analyses. Data were analyzed by the Proc Mixed procedure of SAS (SAS Institute Inc., Cary, NC). Data from daily and frequent sampling periods were analyzed for effects of treatment, time, and treatment by time interactions with repeated measures. Single point variables were analyzed via a one way ANOVA. For the periods of frequent sampling (after sulpiride or TRH), the main effect of group and its interaction with time were analyzed using the Proc Mixed procedures of SAS. When a significant F was detected $(\mathrm{P}<0.05)$, the 
least significant difference (LSD) test (Steel et al., 1997) was used to determine differences between groups within times.

\section{Results}

Before the onset of treatments, one control mare was found to have luteal tissue, as indicated by high progesterone concentrations, and she was therefore dropped from the experiment. After the cessation of sulpiride and vehicle injections, one control mare died as a result of intestinal torsion, thus her date of ovulation was not available; all other data for her were available and were included in the analyses.

Pretreatment of mares with estradiol benzoate before onset of sulpiride injections increased $(\mathrm{P}<0.001)$ prolactin concentrations in morning blood samples 10 to $15 \mathrm{ng} / \mathrm{mL}$ over the concentrations in vehicle-treated mares beginning on d 12 (Figure 2.1). The differences in prolactin concentrations between estradiol-treated and control mares persisted through d 35 .

The frequent blood samples collected after morning injections on d 11, 13, 17, and 27 revealed that the difference $(\mathrm{P}<0.001)$ in prolactin concentrations between estradiol-treated and control mares increased from d 11 to d 17, after which it decreased on d 27 (Figure 2.2). All means except for the $-1 \mathrm{~h}$ and 0 samples on $\mathrm{d} 11$ were different $(\mathrm{P}<0.01)$ between estradiol-treated and control mares.

Administration of TRH on $\mathrm{d} 24$ revealed that the prolactin response to a different prolactin secretagogue was also greater $(\mathrm{P}<0.001)$ in mares pretreated with estradiol benzoate relative to control mares (Figure 2.3). 


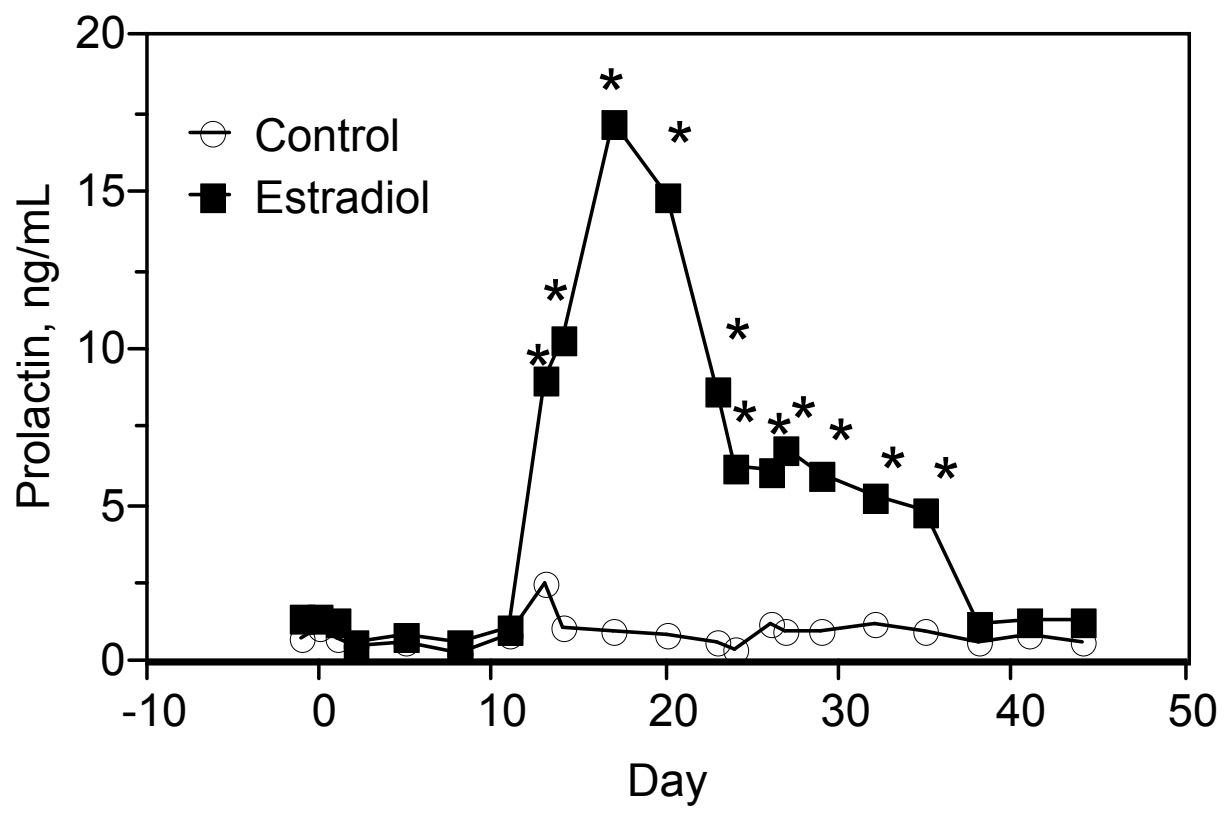

Figure 2.1. Mean plasma concentrations of prolactin over time for mares pretreated with estradiol benzoate (Estradiol) or vehicle (Control) before onset of daily sulpiride treatment (d 11 through 45). Prolactin levels differed $(\mathrm{P}<0.001)$ between groups on days marked with an asterisk. 

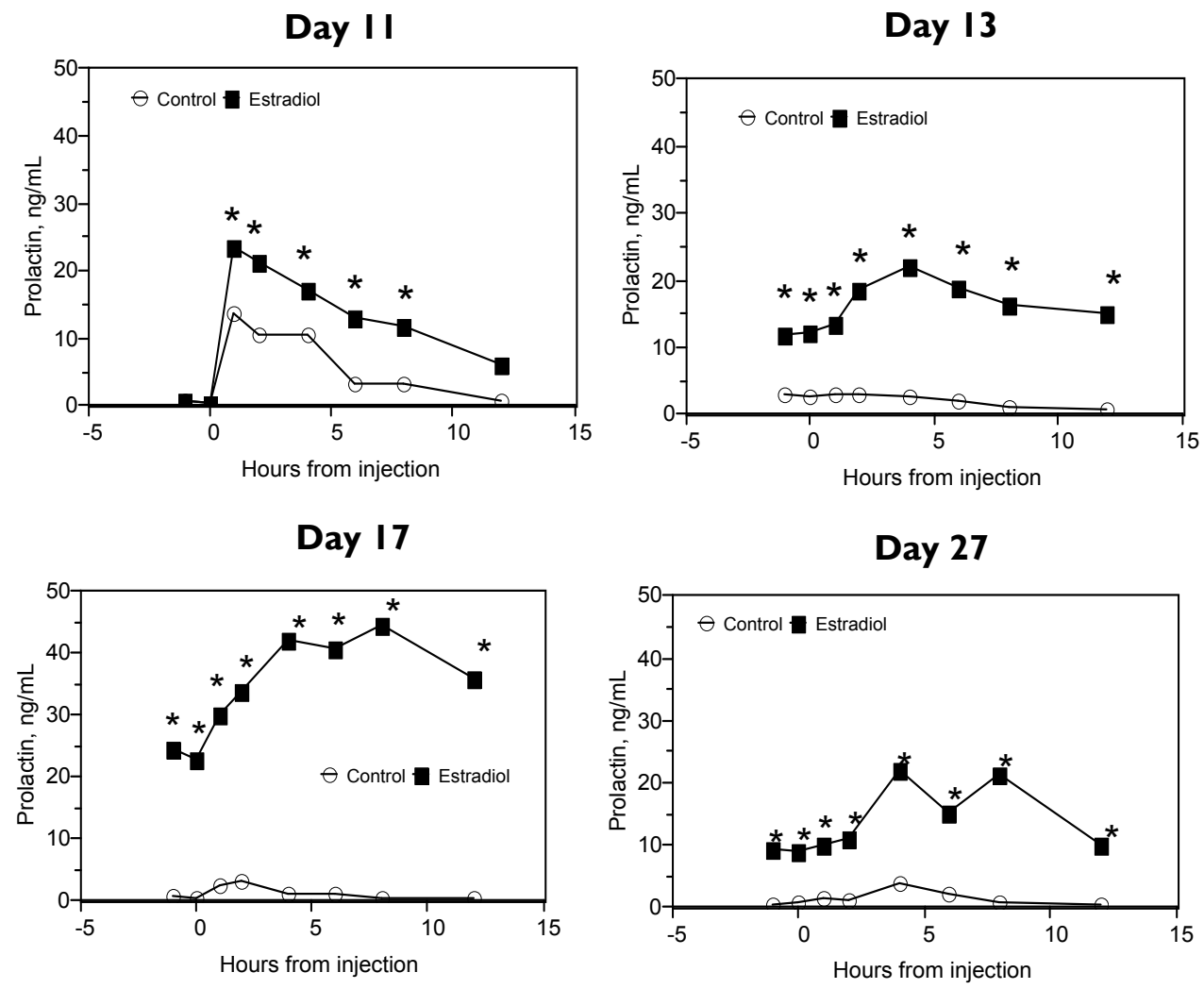

Figure 2.2. Mean plasma prolactin concentrations around the time of sulpiride injections on $\mathrm{d}$ 11 (first injection), 13, 17, and 25 in mares pretreated with estradiol benzoate (Estradiol) or vehicle (Control). Prolactin concentrations were greater $(\mathrm{P}<0.001$; indicated by asterisks) in estradiol-treated mares than in control mares for all time periods except -1 and $0 \mathrm{~h}$ on $\mathrm{d} 11$. 


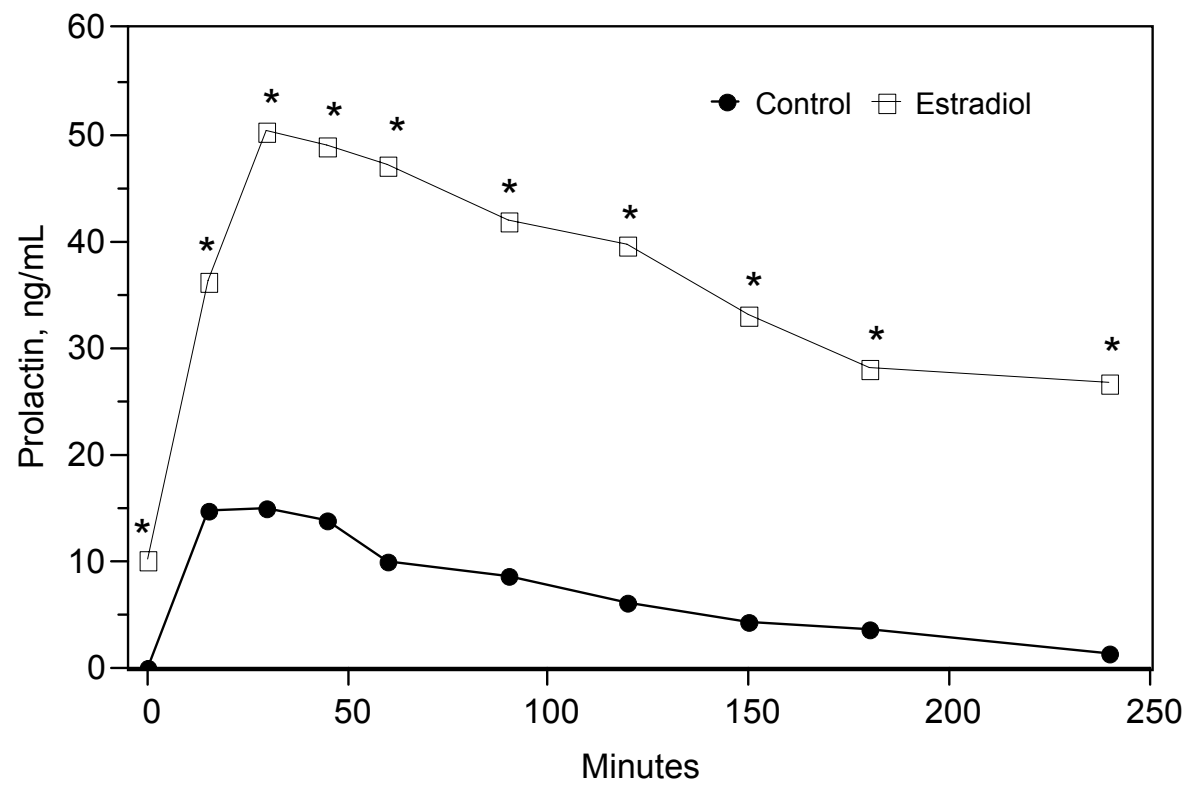

Figure 2.3. Mean plasma prolactin concentrations around the time of TRH administration on $\mathrm{d}$ 24 in mares pretreated with estradiol benzoate (Estradiol) or vehicle (Control). Prolactin concentrations were greater $(\mathrm{P}<0.001)$ in estradiol-treated mares than in control mares for all time periods (indicated by asterisks). 
Mean ages, BCS, and dates of first ovulation for the two groups are presented in Table 2.1. Ages and BCS did not differ $(\mathrm{P}>0.1)$ between groups. Mares pretreated with estradiol benzoate ovulated an average of $45 \mathrm{~d}$ earlier (February $9^{\text {th }} ; \mathrm{P}=0.016$ ) than control mares

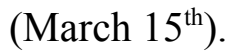

\section{Discussion}

Similar to the results of Donadeu and Thompson (2002), treatment of seasonally anovulatory mares with sulpiride in vegetable shortening in the present experiment (control mares) increased prolactin concentrations, but not to the degree reported for orally administered domperidone (Brendemuehl and Cross, 2000). Moreover, it was revealed by frequent sampling around the injections that the prolactin response to the first sulpiride injection in control mares was much greater than it was after subsequent injections, even $2 \mathrm{~d}$ later. Thompson and Depew (1997) reported a similar drop in the prolactin response to sulpiride administered to geldings in March. They concluded that sulpiride stimulates secretion of prolactin from the pituitary gland, but evidently did not stimulate production of prolactin in the long term.

Table 2.1. Mean age, body condition score (BCS), and day of first ovulation (based on ultrasound exam and progesterone concentration) of mares pretreated with estradiol benzoate or vehicle (control) before daily administration of sulpiride ( $\mathrm{d} 11$ to 45). Estradiol or vehicle injections started on d 0 (January $11^{\text {th }}$ ).

\begin{tabular}{|c|c|c|c|c|}
\hline \multirow[b]{2}{*}{ Item } & \multicolumn{2}{|c|}{ Treatment group } & \multirow[b]{2}{*}{ SEM } & \multirow[b]{2}{*}{ P-value } \\
\hline & Control $^{\mathrm{a}}$ & Estradiol-treated $^{\mathrm{b}}$ & & \\
\hline Age & 12.1 & 10.6 & 1.14 & 0.45 \\
\hline $\mathrm{BCS}$ & 7.1 & 7.5 & 0.35 & 0.36 \\
\hline $\begin{array}{l}\text { Day of first } \\
\text { ovulation }^{c}\end{array}$ & 73.6 & 29.0 & 11.6 & 0.016 \\
\hline
\end{tabular}


Pretreatment of mares in the present experiment with estradiol benzoate approximately doubled the prolactin response to sulpiride after the first injection. This stimulation of prolactin response was hypothesized based on the results of Thompson et al. (1991), who reported a 4- to 5 -fold increase in prolactin content in the pituitary gland of ovariectomized pony mares administered estradiol in oil for $21 \mathrm{~d}$ in the summer. Plasma concentrations of prolactin were also stimulated transiently by estradiol treatment in that experiment (Thompson et al., 1991), but only by $35 \%$ above controls. Thus, it is not surprising that estradiol treatment did not seem to alter plasma prolactin concentrations in the present experiment until onset of sulpiride injections.

By the third day of daily sulpiride injections, estradiol-treated mares had pre-injection prolactin concentrations that were several-fold higher than control mares, indicating that the prolactin response from the earlier sulpiride injections was lasting more than $24 \mathrm{~h}$. Prolactin concentrations in Figure 2.1 reflect pre-injection concentrations (the morning blood samples were drawn before sulpiride injections), and it is evident that these concentrations were highest on $\mathrm{d} 17$ and 20. Prolactin concentrations seemed to decrease quickly after the cessation of estradiol benzoate injections; however, the prolactin response to sulpiride on $\mathrm{d} 27$ was still considerably greater in mares that had received estradiol than in control mares. In fact, prolactin in morning samples were elevated in estradiol-treated mares through d 35.

The TRH injection on $\mathrm{d} 24$ was administered to determine whether stimulation by a different secretagogue for prolactin would provide the same information on prolactin secretion after estradiol treatment as revealed by the frequent sampling around sulpiride injections. In other species, it has been shown that TRH causes the release of prolactin from lactotropes via specific TRH receptors, distinctly different from dopaminergic receptors. The prolactin 
responses in both groups of mares were robust, and seemed to be greater than the prolactin responses to sulpiride on $\mathrm{d} 27$. This was particularly true for the control mares, and may indicate a greater sensitivity of the lactotropes to TRH than to sulpiride at this time.

The greater prolactin response to sulpiride treatment in mares treated with estradiol benzoate was associated with a significant hastening of date of first ovulation. Donadeu and Thompson (2002), who treated mares with sulpiride under similar conditions, had no mares ovulate during $28 \mathrm{~d}$ of treatment, although prolactin concentrations were increased to a degree equal to that of the control mares in the present experiment. Thus, estradiol seemed to provide the missing factor that was needed for hypersecretion of prolactin at this time of the year. In a previous study of horses (Thompson et al., 1994), it was reported that mares and stallions had greater resting prolactin concentrations than geldings, in which estrogen levels would be minimal. In addition, Thompson et al. (1991) reported a direct stimulatory effect of estradiol treatment on prolactin characteristics in ovariectomized pony mares.

It is concluded that estradiol treatment, similar to that in the present experiment, could provide a useful method of increasing the reproductive response of seasonally anovulatory mares to sulpiride administration. Given that Brendemuehl and Cross (2000) had equivalent success with oral domperidone treatment, the question arises as to why sulpiride treatment, without estradiol pretreatment, has not been as successful. Besognet et al. (1997) treated anovulatory mares with sulpiride beginning February 5 and hastened ovulation by $33 \mathrm{~d}$, however it is not clear whether their mares were truly anovulatory or in the early transitional period. The estradiol-treated mares in the present experiment ovulated on the $40^{\text {th }}$ day of the year on the average, which is February 9. Breeders normally start their breeding programs on February 15 to provide a cushion between the subsequent foaling dates and January 1, before 
which they do not want to foal. Therefore the regimen with estradiol and sulpiride in the present experiment seems applicable from the standpoint of timing of breeding in the industry. 


\section{CHAPTER III}

\section{ESTRADIOL INTERACTION WITH A SINGLE INJECTION OF DOMPERIDONE DURING THE BREEDING SEASON IN MARES: PROLACTIN SECRETION AND REPRODUCTIVE TRAITS}

\section{Introduction}

In Chapter II, it was shown that estradiol benzoate pretreatment of seasonally anovulatory mares before a daily regimen of sulpiride increased the prolactin response to sulpiride administration and significantly advanced the date of first ovulation. Thus, the combination of estrogen and sulpiride has potential as a method of inducing ovulation in seasonally quiescent mares. It is likely that the labor involved with daily injections of sulpiride would preclude routine application of such a treatment regimen, thus a simpler alternative method of stimulating prolactin secretion is required. Single-injection, depot administration of compounds encased in bioerodible polymers has been described (Kraeling et al., 2000). The objective of the present experiment was to test whether estradiol pretreatment would enhance the prolactin response to a single, 3-g injection of domperidone in bioerodible polymer, which could potentially be used in lieu of daily sulpiride injections in the winter stimulatory regimen. This experiment was performed in the summer with mares of normal cyclicity.

\section{Materials and methods}

Animals and treatments. Fourteen seasonally cyclic mares ranging in age from 7 to 17 yr with BCS (Henneke et al., 1983) of 6.5 to 8.5 were randomly allotted to 2 treatment groups of 7 mares each. Beginning July 25, they were checked for estrus with a vigorous stallion every other day. Mares in diestrus for at least $6 \mathrm{~d}$ on August 2 were administered PGF $_{2 \alpha}$ (Lutalyse, 2 mg; Pharmacia \& Upjohn Co., New York, NY) to induce luteolysis; mares in estrus or not responding to the August 2 injection were administered $\mathrm{PGF}_{2 \alpha}$ on August 8. Mares were started 
on treatments on the first day they were observed in estrus. Treatments were 1) estradiol benzoate administration as described in Chapter II or 2) vehicle (vegetable oil) injection administered in the same manner (controls). The first day of injection was d 0 . On day 11, all mares received an i.m. injection $(40 \mathrm{~mL})$ of domperidone $(3 \mathrm{~g})$ in bioerodible polymer $(25 \%$ lactide, $25 \%$ glycolide, and 50\% domperidone).

Assessments and blood sampling. All mares were assessed for ovarian and follicular sizes via transrectal ultrasonography every $3 \mathrm{~d}$ until the occurrence of a $25 \mathrm{~mm}$ follicle or larger, after which the mare was assessed daily until ovulation or atresia of the dominant follicle. Morning blood samples were drawn daily by jugular venipuncture starting on $\mathrm{d} 0$ and were continued until d 11; subsequent blood samples were taken every $3 \mathrm{~d}$ until d 46 . Frequent blood samples were drawn from all mares on $\mathrm{d} 11$ at $0,1,3,6$, and $12 \mathrm{~h}$ relative to the domperidone injections.

On $\mathrm{d} 21$, all mares were catheterized in the morning and received an injection of TRH at $10 \mathrm{mg} / \mathrm{kg} \mathrm{BW}$ in saline. Blood samples were drawn at $-15,0,15,30,45,60,90,120,150,180$, and 240 min relative to TRH injection.

Blood samples were collected via jugular venipuncture into sodium heparin coated tubes (Vacutainer, Becton and Dickinson, Franklin Lakes, NJ). Blood samples were routinely centrifuged within 30 min of collection and plasma was harvested and stored frozen. Concentrations of prolactin and progesterone were measured in appropriate plasma samples as described in Chapter II.

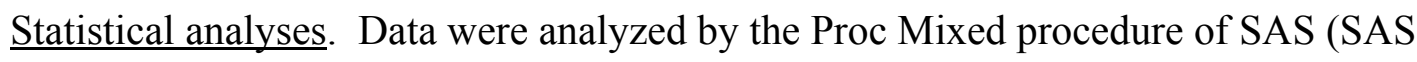
Institute Inc., Cary, NC). Data from daily and frequent sampling periods were analyzed for effects of treatment, time, and treatment by time interactions with repeated measures. Single 
point variables were analyzed via a one-way ANOVA. When a significant $\mathrm{F}$ was detected $(\mathrm{P}<0.05)$, the least significant difference (LSD) test (Steel et al., 1997) was used to determine differences between groups within time

\section{Results}

Treatment of mares with estradiol benzoate starting on the first day of estrus stimulated $(\mathrm{P}<0.05)$ plasma prolactin concentrations on $\mathrm{d} 2,3$, and 6 relative to controls (Figure 3.1). Mares in both groups experienced an increase $(\mathrm{P}<0.001)$ in plasma prolactin concentrations in response to the single, 3-g injection of domperidone in bioerodible polymer on $\mathrm{d} 11$ (Figure 3.2), and the response was higher $(\mathrm{P}<0.01)$ in mares pretreated with estradiol benzoate relative to controls at $1,3,6$, and $12 \mathrm{~h}$ after injection. Plasma prolactin concentrations in mares pretreated with estradiol benzoate remained severalfold higher $(\mathrm{P}<0.05)$ than in control mares through d 31 (Figure 3.1).

On d 21, before injection of TRH, plasma prolactin concentrations in mares pretreated with estradiol benzoate were 3- to 4-fold greater $(\mathrm{P}<0.05)$ than those in control mares (Figure 3.3). Prolactin concentrations after injection of TRH were also greater $(\mathrm{P}<0.001)$ in estradioltreated mares.

Time to ovulation and other reproductive traits are presented in Table 3.1. Time from onset of treatment until ovulation was similar $(\mathrm{P}>0.1)$ in both groups. The time from onset of treatment until return to estrus (determined by a drop in progesterone concentrations), time to next CL formation, and time of second CL regression were not affected $(\mathrm{P}>0.1)$ by estradiol pretreatment. 


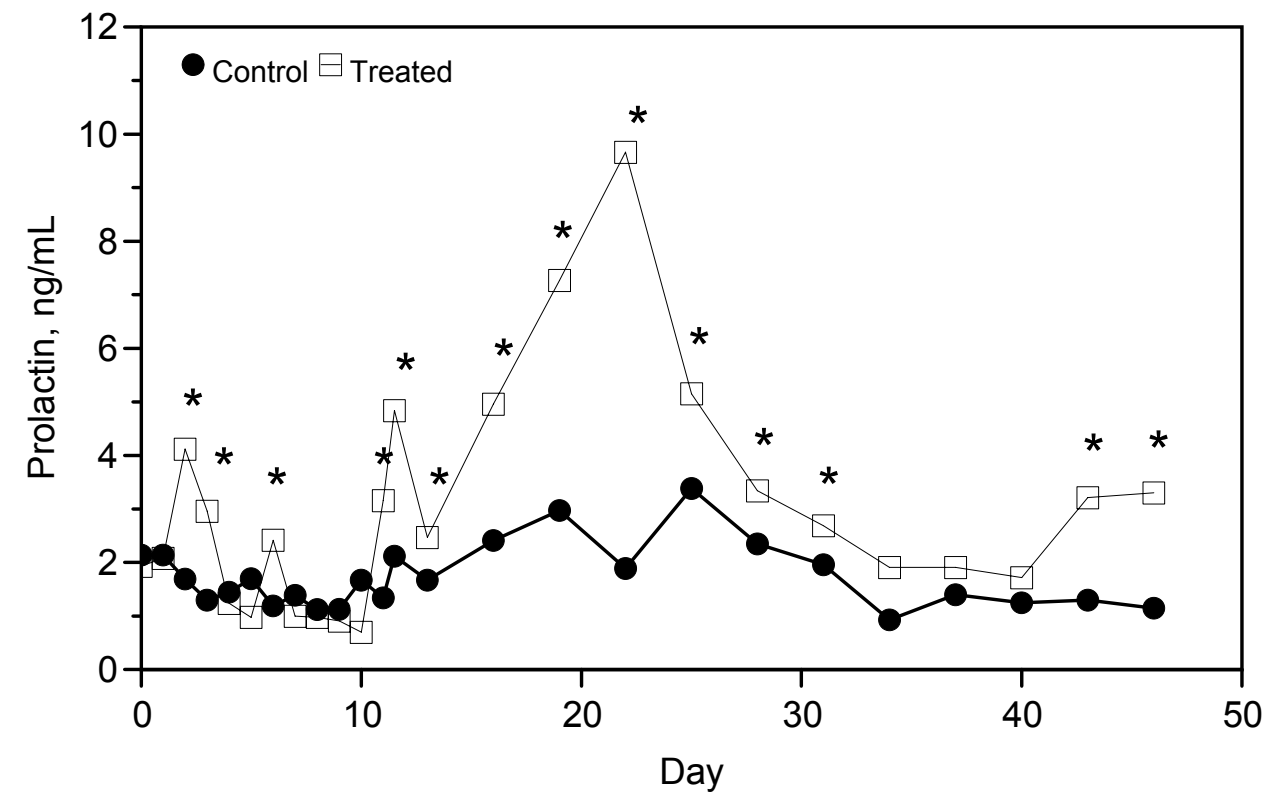

Figure 3.1. Mean plasma concentrations of prolactin over time for mares pretreated starting on $\mathrm{d} 0$ with estradiol benzoate (Estradiol) or vehicle (Control) before a single injection of domperidone on $\mathrm{d} 11$. Prolactin levels differed $(\mathrm{P}<0.001)$ between groups on days marked with an asterisk. 


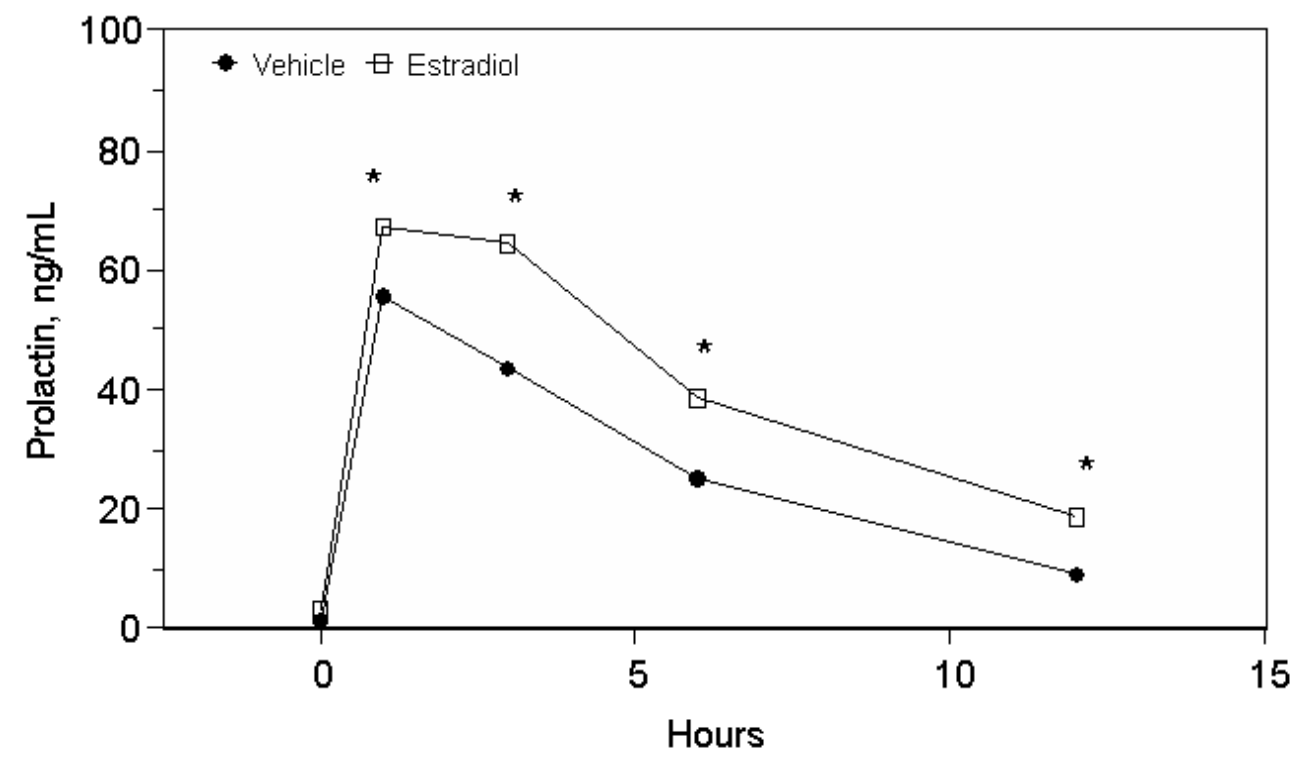

Figure 3.2. Mean plasma prolactin concentrations around the time of domperidone injection on d 11 in mares pretreated with estradiol benzoate (Estradiol) or vehicle (Control). Prolactin concentrations were greater $(\mathrm{P}<0.001$; indicated by asterisks) in estradiol-treated mares than in control mares for all periods after injection. 


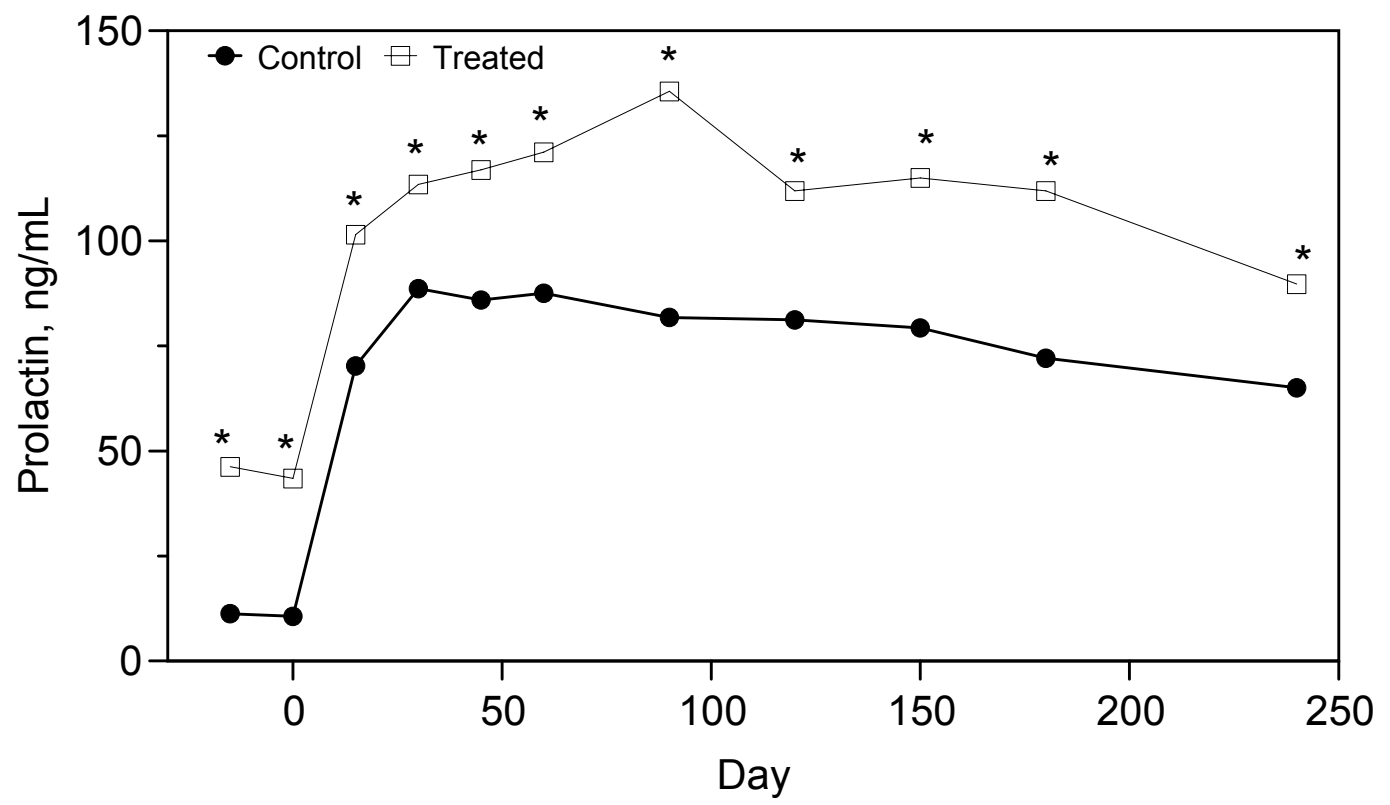

Figure 3.3. Mean plasma prolactin concentrations around the time of TRH administration on $d$ 21 in mares pretreated with estradiol benzoate (Estradiol) or vehicle (Control). Prolactin concentrations were greater $(\mathrm{P}<0.001)$ in estradiol-treated mares than in control mares for all time periods (indicated by asterisks). 
Table 3.1. Mean time to first ovulation, time until CL regression (as determined by a drop in progesterone concentrations), time to next CL formation (high progesterone), and time of second CL regression (drop in progesterone) of mares pretreated with estradiol benzoate or vehicle (control) before a single injection of domperidone on d 11. Estradiol or vehicle injections started on d 0 (first day of estrus).

\begin{tabular}{lllll}
\hline \hline & \multicolumn{2}{c}{ Treatment group $^{\mathrm{a}}$} & & \\
\cline { 2 - 3 } Item & Control & Estradiol-treated & SEM & P-value \\
\hline $\begin{array}{l}\text { Days to } \\
\text { ovulation }\end{array}$ & 6.8 & 6.4 & 0.68 & 0.66 \\
$\begin{array}{l}\text { Days to CL } \\
\text { regression }\end{array}$ & 22.5 & 24.0 & 1.4 & 0.50 \\
$\begin{array}{l}\text { Days to second } \\
\text { ovulation }\end{array}$ & 29.3 & 34.4 & 2.6 & 0.20 \\
$\begin{array}{l}\text { Days to second } \\
\text { CL regression }\end{array}$ & 45.3 & 48.2 & 1.3 & 0.14 \\
\hline \multicolumn{2}{c}{$\mathrm{n}=7$ per group. } & & &
\end{tabular}

\section{Discussion}

Similar to the results presented in Chapter II, pretreatment of cyclic mares in summer with estradiol benzoate significantly enhanced the prolactin response to a single injection of domperidone in bioerodible polymer. In fact, prolactin secretion in both groups of mares increased in response to domperidone, and the duration of stimulation was $20 \mathrm{~d}$. This stimulation, if repeatable in seasonally anovulatory mares in winter, should be long enough such that this single-injection regimen could replace the daily sulpiride injections used in Chapter II; mares in Chapter II ovulated an average of $18 \mathrm{~d}$ after onset of sulpiride injections.

Estradiol pretreatment also increased prolactin concentrations in mares before the domperidone injection, at least in 3 of 10 morning blood samples collected during this time (see Figure 3.1). As reported by Thompson et al. (1991), estradiol treatment for $21 \mathrm{~d}$ had only a 
moderate and transitory effect on plasma prolactin concentrations, but increased pituitary prolactin content severalfold at the end of treatment. Thus, it is possible that the stimulatory effect of estradiol on prolactin secretion may go unnoticed without an extra stimulus, such as sulpiride or domperidone injection. This may explain why Johnson (1986) reported no change in plasma prolactin concentrations across the estrous cycle in mares during the breeding season. It is interesting to note that treatment of mares with estradiol benzoate did not alter the timing of ovulation during treatment nor the timing of CL regression of the subsequent diestrus. Estradiol is a potent inhibitor of FSH secretion in horses (Thompson et al., 1979; Garza et al., 1986), and when given at sufficiently high doses, prevents follicular growth (Woodley et al., 1979). Given the every-other-day injection regimen, the last injection of estradiol benzoate was on d 19, a day or two before regression of the CL from the first diestrus. Thompson (1978) reported that estradiol benzoate injections, as administered here, increased estradiol concentrations in peripheral plasma of geldings to a peak of approximately 60 to $70 \mathrm{pg} / \mathrm{mL}$ at $24 \mathrm{~h}$; concentrations gradually decreased to $25 \mathrm{pg} / \mathrm{mL} 48 \mathrm{~h}$ after injection. Apparently, the dose of estradiol benzoate used in this experiment was not high enough to suppress FSH secretion sufficiently to inhibit follicular growth in preparation for the subsequent (second) estrus. The dose in the present experiment was $11 \mathrm{mg}$ estradiol benzoate every other day, whereas the dose used by Woodley et al. (1979), which inhibited follicular growth, was $10 \mathrm{mg}$ daily. 


\section{SUMMARY AND CONCLUSIONS}

Two experiments were performed to study the possibility of using estradiol pretreatment to enhance prolactin secretion in response to a dopamine receptor antagonist, and to determine if such enhancement increased the success rate of sulpiride treatment for inducing ovarian activity and ovulation in seasonally anovulatory mares. In the first experiment, pretreatment with estradiol benzoate greatly increased the prolactin response to subsequent daily injections of sulpiride. This increase in prolactin response was associated with a significant hastening of the date of ovulation relative to control mares. It was concluded that the combined treatment of estradiol and sulpiride provides a potential practical basis for preparing nonpregnant, anovulatory mares for breeding on February 15.

Because daily injections of sulpiride might prove too labor intensive to be practical, the second experiment tested the possibility of using a single injection of $3 \mathrm{~g}$ of domperidone in bioerodible polymer in lieu of daily sulpiride injections for the stimulation of prolactin secretion. The first experiment was basically repeated with mares in the summer, using the first day of estrus as the starting point for treatment. As in the first experiment, pretreatment with estradiol benzoate enhanced the prolactin response to the injected domperidone, which itself seemed to stimulate prolactin secretion in both groups of mares for $20 \mathrm{~d}$. Estradiol pretreatment did not alter reproductive traits in these mares. It was concluded that the single injection of domperidone likely could replace the daily sulpiride injections used in the first experiment, thereby making that regimen more practical for on-farm use. This possibility needs to be confirmed in future experiments. 


\section{LITERATURE CITED}

Advis, J. P., S. S. White, and S. R. Ojeda. 1981. Delayed puberty induced by chronic suppression of prolactin release in the female rat. Endocrinology 109:1321-1330.

Alexander, S. L., and C. H. G. Irvine. 1993. FSH and LH. Page 45 in Equine Reproduction. A. McKinnon and J. Voss, ed. Williams \& Wilkins, Media, PA.

Aurich, C., P. F. Daels, B. A. Ball, and J. E. Aurich. 1995. Effects of gonadal steroids on the opioid regulation of LH and prolactin release in ovariectomized pony mares. J. Endocrinol. 147:195-202.

Bartke, A. 1980. Role of prolactin in reproduction in male mammals. Fed. Proc. 39:2577-2581.

Ben-Jonathan, N. 1985. Dopamine: A prolactin-inhibiting hormone. Endocr. Rev. 6:564-589.

Besognet, B., B. S. Hansen, and P. F. Daels. 1997. Induction of reproductive function in anestrous mares using a dopamine antagonist. Theriogenology 47:467-480.

Brendemuehl, J. P., and D. L. Cross. 2000. Influence of the dopamine antagonist domperidone on the vernal transition in seasonally anoestrous mares. J. Reprod. Fertil. Suppl. 56:185-193.

Champion, M. C., M. Hartnett, and M. Yen. 1986. Domperidone, a new dopamine antagonist. CMAJ. 135(5):457-461.

Cinquetti, M., P. Bonetti, and P. Bertamini. 2000. Current role of antidopaminergic drugs in pediatrics. Pediatr. Med. Chir. 22:1-7.

Clayton, R. N. 1989. Gonadotrophin-releasing hormone: its actions and receptors. J. Endocrinol. 120:11-19.

Creese, I., D. R. Sibley, and S. Leff. 1983. Classification of dopamine receptors. Adv. Biochem. Psychopharmacol. 37:255-266.

Colborn, D. R., D. L. Thompson Jr., M. S. Rahmanian, and T. L. Roth. 1991. Plasma concentrations of cortisol, prolactin, luteinizing hormone, and follicle-stimulating hormone in stallions after physical exercise and injection of secretagogue before and after sulpiride treatment in winter. J. Anim. Sci. 69:3724-3732.

Daels, P. F., and J. P. Hughes. 1993. The normal estrus cycle. Page 121 in Equine Reproduction. A. McKinnon and J. Voss, ed. Williams \& Wilkins, Media, PA.

Dahlof, C. G., and R. J. Hargreaves. 1998. Pathophysiology and pharmacology of migraine. Is there a place for antiemetics in future treatment strategies? Cephalalgia 18:593-604. 
Donadeu, F. X., and D. L. Thompson Jr. 2002. Administration of sulpiride to anovulatory mares in winter: Effects on prolactin and gonadotropin concentrations, ovarian activity, ovulation and hair shedding. Theriogenology 57:963-976.

Dyer, R. G., and J. E. Robinson. 1989. The LHRH pulse generator. J Endocrinol. 123:1-2.

Fitzgerald, B. P., and C. J. McManus. 2000. Photoperiodic versus metabolic signals as determinants of seasonal anestrus in the mare. Biol. Reprod. 63:335-340.

Freedman, L. J., M. C. Garcia, and O.J. Ginther. 1979. Influence of ovaries and photoperiod on reproductive function in the mare. J. Reprod. Fertil. 27:79-86.

Garza, F., Jr., D. L. Thompson, Jr., R. L. St. George, and D. D. French. 1986. Androgen and estradiol effects on gonadotropin secretion and response to $\mathrm{GnRH}$ in ovariectomized pony mares. J. Anim. Sci. 62:1654-1659.

Gentry, L. R., D. L. Thompson, Jr., G. T. Gentry, Jr., K. A. Davis, R. A. Godke, and J. A. Cartmill. 2002a. The relationship between body condition, leptin, and reproductive and hormonal characteristics of mares during the seasonal anovulatory period. J. Anim. Sci. 80:2695-2703.

Gentry, L. R., D. L. Thompson, Jr., and A. M. Stelzer. 2002b. Treatment of seasonally anovulatory mares with thyrotropin releasing hormone and(or) gonadotropin releasing hormone analog. J. Anim. Sci. 80:208-213.

Ginther, O. J. 1992. Reproductive Biology of the Mare. 2nd ed. Equiservices, Cross Plains, WI.

Ginther, O. J., M. A. Beg, D. R. Bergfelt, F. X. Donadeu, and K. Kot. 2001. Follicle selection in monovular species. Biol. Reprod. 65:638-647.

Ginther, O. J., and D. R. Bergfelt. 1993. Growth of small follicles and concentrations of FSH during the equine oestrous cycle. J. Reprod. Fertil. 99:105-111.

Gershengorn, M. C., B. E. Marcus-Samuels, and E. Geras. 1979. Estrogens increase the number of thyrotropin-releasing hormone receptors on mammotropic cells in culture.

Endocrinology 105:171-176.

Guyton, A. C., and J. E. Hall. 1996. Textbook of Medical Physiology. 9th Ed. W. B. Saunders, Philadelphia.

Hadley, M. E. 2000. Endocrinology. Prentice Hall, Inc., Upper Saddle River, New Jersey. Pages 97-99, 517-518, 525.

Henneke, D. R., G. D. Potter, J. L. Kreider, and B. F. Yeates. 1983. Relationship between condition score, physical measurements and body fat percentage in mares. Equine Vet. J. 15:371-372. 
Hines, K. K., K. J. Affleck, S. P. Barrows, W. L. Murdoch, B. P. Fitzgerald, and R. G. Loy. 1991. Follicle stimulating hormone pulse amplitude decreases with the onset of the breeding season in the mare. Biol. Reprod. 44:516-521.

Johnson, A. L. 1986. Serum concentrations of prolactin, thyroxine and triiodothyronine relative to season and the estrous cycle in the mare. J. Anim. Sci. 62:1012-1020.

Johnson, A. L., and S. E. Becker. 1987. Effects of physiologic and pharmacologic agents on serum prolactin concentrations in the nonpregnant mare J. Anim. Sci. 65:1292-1297.

Johnson, A. L., and K. Malinowski. 1986. Daily rhythm of cortisol, and evidence for a photoinducible phase for prolactin secretion in nonpregnant mares housed under noninterrupted and skeleton photoperiods. J. Anim. Sci. 63:169-175.

Jones, P. B., and A. J. Hsueh. 1981. Regulation of progesterone-metabolizing enzyme by adrenergic agents, prolactin, and prostaglandins in cultured rat ovarian granulosa cells. Endocrinology 109:1347-1354.

Kainer, R. A. 1993. Reproductive organs of the mare. Page 5 in Equine Reproduction. A. McKinnon and J. Voss, ed. Williams \& Wilkins, Media, PA.

Kebabian, J. W., and D. B. Calne. 1979. Multiple receptors for dopamine. Nature 277:93-106.

King, S. S., A. G. Campbell, E. A. Dille, J. F. Roser, L. L. Murphy, and K. L. Jones. 2005. Dopamine receptors in equine ovarian tissues. Domest. Anim. Endocrinol. 28:405-415.

Kooistra, L. H., and O. J. Ginther. 1975. Effect of photoperiod on reproductive activity and hair in mares. Am. J. Vet. Res. 36:1413-1419.

Kraeling, R. R., C. R. Barb , G. B. Rampacek, D. L. Thompson Jr., J. W. Gibson, S. A. Sullivan, B. Simon, and P. J. Burns. 2000. Luteinizing hormone response to controlled-release deslorelin in estradiol benzoate primed ovariectomized gilts. Theriogenology 53:1681-1689.

Lincoln, G. A., and D. J. Tortonese. 1995. Does melatonin act on dopaminergic pathways in the mediobasal hypothalamus to mediate effects of photoperiod in the ram. Neuroendocrinology 62:425-433.

Miller, K. F., S. L. Berg, D. C. Sharp, and O. J. Ginther. 1980. Concentrations of circulating gonadotropins during various reproductive states in mares. Biol. Reprod. 22:744-750.

Miller, K. F., J. A. Wesson, and O. J. Ginther. 1981. Interaction of estradiol and a nonsteroidal follicular fluid substance in the regulation of gonadotropin secretion in the mare. Biol. Reprod. 24:354-358. 
Munemura, M., T. E. Cote, K. Tsuruta, R. L. Eskay, and J. W. Kebabian. 1980. The dopamine receptor in the intermediate lobe of the rat pituitary gland: Pharmacological characterization. Endocrinology 107:1676-1683.

Nadal, M. R., D. L. Thompson, Jr., and L. A. Kincaid. 1997. Effect of feeding and feed deprivation on plasma concentrations of prolactin, insulin, growth hormone, and metabolites in horses. J. Anim. Sci. 75:736-744.

Neill, J. D., L. S. Frawley, P. M. Plotsky, and G. T. Tindall. 1981. Dopamine in hypophysial stalk blood of the rhesus monkey and its role in regulating prolactin secretion. Endocrinology 108:489-494.

Nett, T. M. 1993. Reproductive peptide and protein hormones. Page 110 in Equine Reproduction. A. McKinnon and J. Voss, ed. Williams \& Wilkins, Media, PA.

Nequin, L. G., S. S. King, A. L. Johnson, G. M. Gow, and G. M. Ferreira-Dias. 1993. Prolactin may play a role in stimulating the equine ovary during the spring transition. J. Equine Vet. Sci. 13:631-635.

Niswender, G. D., and T. M. Nett. 1993. Luteal phase. Page 172 in Equine Reproduction. A. McKinnon and J. Voss, ed. Williams \& Wilkins, Media, PA.

Oxender, W. D., P. A. Noden, and H. D. Hafs. 1977. Estrus, ovulation, and serum progesterone, estradiol, and LH concentrations in mares after an increased photoperiod during winter. Am. J. Vet. Res. 38:203-207.

Pierson, R. A. 1993. Folliculogenesis and ovulation. Page 161 in Equine Reproduction. A. McKinnon and J. Voss, ed. Williams \& Wilkins, Media, PA.

Pruett, H. E., D. L. Thompson, Jr., J. A. Cartmill, C. C. Williams, and L. R. Gentry. 2003. Thyrotropin releasing hormone interactions with growth hormone secretion in horses. J. Anim. Sci. 81:2343-2351.

Purvis, K., and V. Hansson. 1978. Hormonal regulation of Leydig cell function. Mol. Cell. Endocrinol. 12:123-138.

Rahmanian, M. S., D. L. Thompson Jr., and P. A. Melrose. 1997. Immunocytochemical localization of prolactin and growth hormone in the equine pituitary. J. Anim. Sci. 75:3010-3018.

Redmond, L. M., D. L. Cross, J. R. Strickland, and S. W. Kennedy. 1994. Efficacy of domperidone and sulpiride as treatments for fescue toxicosis in horses. Am. J. Vet. Res. 55:722-729. 
Roser, J. F., B. L. Kiefer, J. W. Evans, D. P. Neely, and C. A. Pacheco. 1979. The development of antibodies to human chorionic gonadotropin following its repeated injection in the cyclic mare. J. Reprod. Fertil. Suppl. 27:173-179.

Sharp, D. C., and S. D. Davis. 1993. Vernal transition. Page in 133 in Equine Reproduction. A. McKinnon and J. Voss, ed. Williams \& Wilkins, Media, PA.

Sharp, D. C., L. Kooistra, and O. J. Ginther. 1975. Effects of artificial light on the oestrous cycle of the mare. J. Reprod. Fertil. Suppl. 23:241-246.

Silvia, P. J., E. L. Squires, and T. M. Nett. 1986. Changes in the hypothalamic hypophyseal axis of mares associated with seasonal reproductive recrudescence. Biol. Reprod. 35:897-905.

Snyder, D. A., D. D. Turner, K. F. Miller, M. C. Garcia, and O. J. Ginther. 1979. Follicular and gonadotrophic changes during transition from ovulatory to anovulatory seasons. J. Reprod. Fert. Suppl. 27:95-101.

Steel, R. G. D., J. H. Torrie, and D. A. Dickey. 1997. Principles and Procedures of Statistics: A Biometrical Approach (3rd ed). McGraw-Hill book Co., New York.

Thomson, C. H., D. L. Thompson, Jr., L. A. Kincaid, and M. R. Nadal. 1996. Prolactin involvement with the increase in seminal volume after sexual stimulation in stallions. J. Anim. Sci. 74:2468-2472.

Thompson, D. L., Jr. 1978. Effects of estradiol-17 $\beta$ and testosterone on semen, sexual behavior and gonadotropins in geldings. Ph.D. Dissertation. Colorado State University, Fort Collins.

Thompson, D. L. Jr., and C. L. DePew. 1997. Prolactin, gonadotropin, and hair shedding responses to daily sulpiride administration in geldings in winter. J. Anim. Sci. 75:1087-1091.

Thompson, D. L., Jr., C. L. Depew, A. Ortiz, L. S. Sticker, and M. S. Rahmanian. 1994. Growth hormone and prolactin concentrations in plasma of horses: Sex differences and the effects of acute exercise and administration of growth hormone releasing hormone. J. Anim. Sci. 72:2911-2918.

Thompson, D. L., Jr., F. Garza, Jr., R. L. St. George, M. H. Rabb, B. E. Barry, and D. D. French. 1991. Relationships among LH, FSH and prolactin secretion, storage and response to secretagogue and hypothalamic GnRH content in ovariectomized pony mares administered testosterone, dihydrotestosterone, estradiol, progesterone, dexamethasone or follicular fluid. Domest. Anim. Endocrinol. 8:189-199. 
Thompson, D. L., Jr., R. Hoffman, and C. L. DePew. 1997. Prolactin administration to seasonally anestrous mares: Reproductive, metabolic, and hair shedding responses. J. Anim. Sci. 75:1092-1099.

Thompson, D. L., Jr., and L. Johnson. 1987. Effects of age, season and active immunization against estrogen on serum prolactin concentrations in stallions. Domest. Anim. Endocrinol. 4:17-22.

Thompson, D. L., Jr., L. Johnson, R. L. St. George, and F. Garza, Jr. 1986. Concentrations of prolactin, LH, and follicle stimulating hormone in pituitary and serum of horses: Effect of sex, season, and reproductive state. J. Anim. Sci. 63:854-860.

Thompson, D. L., Jr., D. R. McNeill, J. J. Wiest, R. L. St. George, L. S. Jones, and F. Garza, Jr. 1987. Secretion of luteinizing hormone and follicle stimulating hormone in intact and ovariectomized mares in summer and winter. J. Anim. Sci. 64:247-253.

Thompson, D. L., Jr., B. W. Pickett, E. L. Squires, and T. M. Nett. 1979. Effect of testosterone and estradiol-17ß alone and in combination on LH and FSH concentrations in pituitary and blood serum of geldings and in serum after GnRH. Biol. Reprod. 21:1231-1237.

Van Straalen, R. J., and G. H. Zeilmaker. 1982. Observations on the effects of prolactin on LH-receptors and steroidogenesis in corpus luteum and testis of the hypophysectomized rat. Acta Endocrinol. (Copenh) 99:437-442.

Voss, J. L. 1993. Human chorionic gonadotropin. Page 325 in Equine Reproduction. A. McKinnon and J. Voss, ed. Williams \& Wilkins, Media, PA.

Woodley, S. L., P. J. Burns, R. H. Douglas, and W. D. Oxender. 1979. Prolonged interovulatory interval after oestradiol treatment in mares. J. Reprod. Fertil. Suppl. 27:205-209. 


\section{VITA}

Kristian Kandis Kelley, daughter of Chantelle Peterson and Donna and Wendell Kelley, and granddaughter of Louise Wyrick, was born in Magnolia, Arkansas. She attended high school in her hometown until May, 2000. She then enrolled at Southern Arkansas University in Magnolia beginning in the Fall of 2000 and continued there until May of 2004, at which time she received the bachelor of science in biology with a minor in psychology. In August of 2004, Kristian moved to Baton Rouge, Louisiana, to attend Louisiana State University and pursue the master of science degree in the Department of Animal Sciences with an emphasis on equine physiology and endocrinology, under the direction of Professor Donald L. Thompson, Jr. 